\title{
UPAYA PEMENUHAN KEBUTUHAN HIDUP PETANI KOPI DI DESA HARJOMULYO KECAMATAN SILO KABUPATEN JEMBER
}

\author{
Elok Asiyah Ulfa ${ }^{1}$, Retna Ngesti $S^{1}$, Sutrisno Djaja ${ }^{1}$ \\ ${ }^{1}$ Program Studi Pendidikan Ekonomi, Fakultas Keguruan dan Ilmu Pendidikan, Universitas Jember \\ e-mail: elokasiyah19@gmail.com
}

\begin{abstract}
Abstrak
Petani kopi di Desa Harjomulyo memiliki permasalahan dalam kesejahteraan ekonomi, seperti masa panen yang lama, lahan yang sempit, serta kebutuhan hidup yang lebih besar daripada pendapatan bertani kopi. Sehingga untuk menyelesaikan permasalahan tersebut, petani kopi memerlukan berbagai upaya dalam memenuhi kebutuhan hidupnya. Penelitian ini bertujuan untuk mendeskripsikan upaya pemenuhan kebutuhan petani kopi di Desa Harjomulyo Kecamatan Silo Kabupaten Jember. Jenis penelitian yang digunakan adalah deskriptif kualitatif dengan subjek penelitian adalah petani kopi di Desa Harjomulyo Kecamatan Silo Kabupaten Jember. Dalam penelitian ini menggunakan jenis data primer dan sekunder. Metode pengumpulan data yang digunakan adalah metode wawancara, observasi dan dokumen. Sedangkan metode analisis data menggunakan analisis data kualitatif dengan penjelasan deskriptif. Teknik pemeriksaan keabsahan data menggunakan triangulasi. Hasil penelitian menunjukkan bahwa petani kopi di Desa Harjomulyo Kecamatan Silo Kabupaten Jember menggunakan upaya pekerjaan sampingan untuk bisa memenuhi kebutuhan hidup petani kopi dan keluarga petani kopi. Upaya yang dilakukan petani kopi ada 3 macam yaitu menanam lahan tumpang sari, membuat gerai dari bambu, bekerja keluar kota. Berdasarkan hasil penelitian ini, kami menyimpulkan bahwa petani kopi di Desa Harjomulyo Kecamatan Silo Kabupaten Jember menerapkan upaya pekerjaan sampingan dalam memenuhi kebutuhan hidupnya dan kebutuhan hidup keluarganya.
\end{abstract}

Kata Kunci: Petani kopi, upaya pemenuhan kebutuhan hidup, Desa Harjomulyo, Kabupaten Jember

\begin{abstract}
Coffee farmers in Harjomulyo Village have problems in economic welfare, such as long harvest time, limited area for coffee farming, and the necessities of life greater than coffee farming income. So, the solution of the problem, coffee farmers need various efforts in completing their needs. This study aims to describe efforts to complete the needs of coffee farmers in the Village Harjomulyo Silo District Jember. The type of research used was qualitative descriptive with research subject is coffee farmer in Harjomulyo Village, Silo Subdistrict, Jember Regency. In this study was using primary and secondary data types. Data collection methods used were interview, observation and document method. While the method of data analysis using qualitative data analysis with descriptive explanation. Technique examination of data validity use triangulation. The results showed that coffee farmers in Harjomulyo Village, Silo District, Kabupaten Jember, used side work to complete the needs of coffee farmers and coffee farming families. Efforts made coffee farmers there are 3 kinds of planting land intercropping, making outlets from bamboo, working out of town. Based on the results of this study, we conclude that coffee farmers in Harjomulyo Village, Silo Sub-district, Jember Regency, have implemented side-by-side efforts to completing their life needs and family's living needs.
\end{abstract}

Keywords: Coffee farmer, effort fulfillment needs, Harjomulyo Village, Jember Regency

\section{PENDAHULUAN}

Sejak era kolonial Belanda sampai saat ini, kawasan ujung timur Jawa Timur dikenal sebagai sentra perkebunan kopi. Wilayah ini juga menjadi basis perkebunan kopi terbesar di Indonesia dengan jumlah 123 kebun kopi, yang tersebar di Kabupaten Jember, Bondowoso, Banyuwangi, dan Situbondo. Perkebunanperkebunan tersebut didirikan sejak tahun 1990 sampai 1967. Sebagian besar kini menjadi perkebunan milik negara, swasta, dan sebagian kecil lainnya merupakan perkebunan kopi rakyat.

Salah satu wilayah di Indonesia yang memiliki kegiatan pertanian kopi adalah Jawa Timur, salah satunya di Kabupaten Jember. Menurut data BPS tahun 2017, sebaran luas areal kopi rakyat di Kabupaten Jember saat ini mencapai $6.245,01$ ha yang tersebar hampir di seluruh kecamatan dengan sentra areal kopi berada di 8 kecamatan yaitu Kecamatan Silo, Jelbuk, Ledokombo, Sumberjambe, Panti, Tanggul, dan Sumberbaru. Pertanian kopi di Kecamatan Silo, khususnya Desa Harjomulyo terletak pada wilayah datar sedang 
yang luasnya merupakan dataran yang subur. Namun, kenyataan yang terjadi pada sektor perkopian, khususnya kopi rakyat, masih dihadapkan pada banyak masalah.

Berbagai hal menjadi pokok masalah yang mempengaruhi kesejahteraan hidup masyarakat petani kopi di Desa Harjomulyo. Kendala yang mempengaruhi kesejahteraan hidup petani kopi di Desa Harjomulyo adalah rendahnya pendidikan, sempitnya lahan yang dimiliki petani kopi, masa panen yang sangat lama, kebutuhan yang harus dipenuhi setiap hari, dan juga pendapatan utama petani kopi sangat rendah sehingga tidak cukup untuk memenuhi kebutuhan hidup. Hal itu membuat petani kopi tidak bisa berhasil meningkatkan kesejahteraan ekonomi untuk keluarganya. Oleh sebab itu petani kopi mengupayakan bekerja sampingan diluar tani kopi (off farm) untuk memenuhi kebutuhan hidupnya dan kebutuhan hidup keluarganya.

Penggunaan tenaga kerja oleh keluarga petani di negara berkembang pada umumnya, tidak hanya bekerja untuk on farm, tetapi juga off farm dan non farm, terutama pada usahatani skala kecil (berdasarkan ukuran luas lahan atau jumlah ternak yang diusahakan) Farida (2013), hal itu menunjukkan bahwa petani kopi yang bekerja di pertanian belum tentu dapat memenuhi kebutuhannya, sehingga petani kopi tersebut melakukan pekerjaan diluar usaha tani (Off Farm).

Kebutuhan hidup petani kopi merupakan kebutuhan yang harus dipenuhi dalam melangsungkan hidupnya. Sudarto (2003: 15) menyebutkan bahwa kebutuhan yang harus terpenuhi untuk kelangsungan hidup manusia, terdiri dari seperti makan, minum, pakaian, maupun kebutuhan pelayanan sosial yang berupa transportasi, kesehatan, serta pendidikan. Seiring berkembangnya jaman dan berbagai kebutuhan yang semakin lama semakin beragam, maka pendapatan keluarga petani kopi pun juga tidak cukup untuk memenuhi kebutuhan yang ada. Hal ini kami temukan pada hasil observasi sebelumnya pada petani kopi di Desa Harjomulyo, yang menunjukkan bahwa kebutuhan hidup petani kopi dan keluarganya lebih besar daripada pendapatan yang diterima. Meskipun demikian petani kopi harus tetap memenuhi kebutuhan hidupnya agar kelangsungan hidupnya tetap berjalan dengan baik.

Dengan pendapatan utama sebagai petani kopi, memiliki lahan yang sempit dan waktu panen yang lama membuat petani kopi tidak bisa memenuhi kebutuhan hidupnya dalam sehari-hari jika hanya mengandalkan pendapatan utama. Sehingga diperlukan berbagai upaya untuk memenuhi kebutuhan hidup petani kopi dan keluarganya, yaitu dengan mencari pendapatan sampingan selain menjadi petani kopi.

Berdasarkan uraian latar belakang di atas, kami tertarik untuk melakukan penelitian dengan tujuan untuk mendeskripsikan upaya pemenuhan kebutuhan petani kopi di Desa Harjomulyo Kecamatan Silo Kabupaten Jember.

\section{METODE}

Penelitian yang dilakukan merupakan penelitian studi kasus, deskriptif kualitatif. Penelitian dilakukan di lokasi pertanian kopi di Desa Harjomulyo Kecamatan Silo Kabupaten Jember. Metode penentuan lokasi yang digunakan dalam penelitian ini adalah metode purposive area, sedangkan untuk penentuan subjek penelitian menggunakan teknik Snowball pada petani kopi di Desa Harjomulyo Kecamatan Silo Kabupaten Jember.

Subjek dibedakan menjadi dua, yaitu: a) Informan utama merupakan subjek yang memberikan sumbangan data utama dalam penelitian ini yaitu petani kopi dengan syarat memiliki lahan kopi kurang dari 2 ha, memiliki istri, memiliki anak yang sedang menempuh pendidikan, mempunyai pekerjaan sampingan; b) Informan pendukung dalam penelitian ini yaitu istri petani kopi dan perangkat desa di Desa Harjomulyo Kecamatan Silo Kabupaten Jember.

Untuk pengumpulan data menggunakan 3 metode yaitu:

a) Metode wawancara, proses wawancara yang dilakukan dalam penelitian ini adalah wawancara secara mendalam, dengan menggunakan pedoman wawancara terstruktur yang ditujukan kepada informan yaitu petani kopi di Desa Harjomulyo yang mempunyai lahan dan mempunyai penghasilan tambahan dari pekerjaan sampingan.

b) Metode observasi, pada tahap ini, peneliti melakukan observasi dengan datang secara langsung untuk melihat kondisi rumah beserta perabotan yang dimiliki petani kopi di Desa Harjomulyo Kecamatan Silo Kabupaten Jember.

c) Metode dokumen. Adapun dokumen yang ingin peneliti dapatkan pada penelitian ini adalah mengenai profil desa, mata pencaharian masyarakat dan data-data umum lainnya yang berkaitan dengan Desa Harjomulyo Kecamatan Silo Kabupaten Jember.

Selanjutnya, data dianalisis berdasarkan tahapan:

1) Data Reduction (reduksi data), reduksi data yang dilakukan yaitu memilah dan memfokuskan tentang bagaimana upaya pemenuhan kebutuhan hidup petani kopi di Desa Harjomulyo Kecamatan Silo Kabupaten Jember. 
2) Data Display (penyajian data), penyajian data kualitatif disajikan dalam bentuk teks naratif, bisa juga dalam bentuk matrik, grafik, jaringan dan bagan. Hal ini bertujuan memudahkan membaca dan menarik kesimpulan, disesuaikan dengan perumusan masalah yang telah ditentukan.

3) Penarikan kesimpulan, setelah data disajikan adalah penarikan kesimpulan atau kegiatan akhir yang dipaparkan. Kesimpulan dalam penelitian ini diharapkan dapat mendeskripsikan upaya pemenuhan kebutuhan hidup petani kopi di Desa Harjomulyo Kecamatan Silo Kabupaten Jember. Temuan ini dapat berupa deskripsi maupun gambaran dari suatu obyek yang awalnya masih belum jelas, setelah dilakukan penelitian menjadi lebih jelas.

\section{HASIL DAN PEMBAHASAN Hasil Penelitian}

Pemenuhan kebutuhan hidup petani kopi dapat dilihat dari pendapatan yang diperoleh oleh petani kopi. Pendapatan merupakan salah satu sumber dana bagi keluarga, dalam kehidupan sehari-hari pendapatan merupakan sejumlah uang atau barang yang diterima oleh seseorang dalam jangka waktu tertentu sebagai balas jasa atas faktor-faktor produksi yang telah dikorbankan. Sama halnya dengan pendidikan, tingkat pendapatan dapat menentukan status sosial ekonomi seseorang di masyarakat. Semakin tinggi pendapatan seseorang, maka semakin tinggi pula kemampuan orang tersebut dalam memenuhi kebutuhan.

\section{Pendapatan Utama Petani Kopi}

Menurut Tohar (2000:46) pendapatan pokok seseorang berasal dari pendapatan yang diterima dari pekerjaan utama secara rutin. Berdasarkan teori tersebut dapat disimpulkan bahwa pendapatan pokok sangat penting di dapatkan secara rutin. Seseorang tidak akan bisa memenuhi kebutuhan hidupnya jika hanya mengandalkan dari pendapatan utama yang tidak bisa didapatkan secara rutin. Karena untuk memenuhi kebutuhan hidup diperlukan biaya yang tidak sedikit. Sehingga seseorang harus berusaha untuk memenuhi kebutuhan hidupnya dengan mendapatkan hasil dari pendapatannya secara rutin. Jika pendapatan pokok tidak dapat memenuhi kebutuhan hidup dalam sehari-hari, maka pendapatan sampingan dapat membantu untuk memenuhi kebutuhan hidup dalam sehari-hari.

Tabel 1. Rata-rata Pendapatan Utama Petani Kopi Per Tahun

\begin{tabular}{|c|c|c|c|}
\hline No. & Nama Informan & Rata-rata Pendapatan Per Th & Luas Tanah \\
\hline 1 & Bapak Hengki & $\mathrm{Rp} 12.000 .000$ & $1 \mathrm{Ha}$ \\
\hline 2 & Bapak Syamsul & Rp 18.000.000 & $1 \frac{1}{2} \mathrm{Ha}$ \\
\hline 3 & Bapak Warsis & Rp 18.000.000 & $1 \frac{1}{2} \mathrm{Ha}$ \\
\hline 4 & Bapak khalik & Rp 12.000.000 & $1 \mathrm{Ha}$ \\
\hline 5 & Bapak Junaidi & $\mathrm{Rp} 18.000 .000$ & $1 \frac{1}{2} \mathrm{Ha}$ \\
\hline \multicolumn{2}{|c|}{ Rerata pendapatan petani kopi } & \multicolumn{2}{|l|}{ Rp 15.600.000 per tahun } \\
\hline
\end{tabular}

Sumber: diolah dari Data Primer 2017

Dari pendapatan informan penelitian dapat peneliti simpulkan bahwa lahan yang dimiliki oleh petani sangat mempengaruhi pendapatan yang diterima petani kopi dalam jangka waktu 1 tahun itu dari setiap panen. Namun semua informan penelitian masih harus membayar hutang, menggaji buruh, dan biaya tanaman kopi. Sehingga tidak cukup untuk memenuhi kebutuhan hidupnya di tahun yang akan datang.

Petani kopi tidak bisa menabung dengan pendapatan yang diterima dari hasil panen kopi yang tergolong sedikit daripada petani kopi yang memiliki lahan yang cukup luas. Petani kopi yang memiliki lahan kecil ini hanya mendapatkan rata-rata Rp 15.600.000 pertahun, uang dengan jumlah tersebut tidak bisa ditabung untuk memenuhi kebutuhan hidup 1 tahun yang akan mendatang. Sehingga petani kopi tidak bisa memenuhi kebutuhan hidupnya jika hanya mengandalkan hasil dari panen kopi 1 tahun sekali. Petani kopi memilih untuk hutang terlebih dahulu untuk sekedar memenuhi kebutuhan pokok keluarganya dalam sehari-hari, dan untuk membayarnya petani kopi memilih untuk memotong hasil dari panen kopi untuk melunasi semua hutanghutangnya. Sehingga pendapatan dari panen kopi tidak sepenuhnya diterima semua. Karena sebagian untuk membayar hutang, sebagian lagi untuk membayar upah buruh, mengganti tanaman kopi yang sudah tidak bisa menghasilkan kopi, untuk biaya perawatan dan lain sebagainya.

\section{Pendapatan Sampingan Petani Kopi}

Pendapatan sampingan merupakan pendapatan yang diperoleh dari bekerja diluar pekerjaan utama. Dalam penelitian ini pekerjaan sampingan ini sebagai Upaya untuk menambah penghasilan dari pekerjaan utama, sehingga petani kopi dapat memenuhi kebutuhan hidupnya dalam sehari-hari. Petani kopi harus mencari pekerjaan alternatif lainnya dengan semua potensi yang sudah ada. Berdasarkan hasil wawancara dengan beberapa informan penelitian. Terdapat beberapa pekerjaan sampingan yang dilakukan oleh petani kopi di Desa Harjomulyo Kecamatan Silo Kabupaten Jember, yaitu bekerja sampingan (Menanam lahan tumpang sari, membuat gerai dari bambu dan bekerja keluar kota). Berikut penjelasan tentang pendapatan sampingan yang 
dilakukan oleh petani kopi:

\section{a) Penanaman Lahan Tumpang Sari}

Penanaman lahan tumpang sari ini merupakan tanaman yang ditanam di sekitar lahan kopi, Tumpangsari digunakan untuk meningkatkan produktivitas lahan, mengurangi resiko usaha tani, serta menjamin kelangsungan pendapatan. Jenisnya disesuaikan dengan kebutuhan petani, peluang pasar, nilai ekonomi dan iklim mikro yang ada. Salah satu jenis yang ditanami tumpang sari adalah Pisang dan cabai. Penanaman lahan tumpang sari di lakukan petani kopi untuk menutupi kekurangan pendapatan yang ada untuk memenuhi kebutuhan hidup dalam sehari-hari. Seperti yang diungkapkan oleh salah satu petani kopi:

"Saya bekerja sampingan menanam lahan tumpang sari pisang dan cabai mbak. Kalau pisang jenisnya pisang raja. Panennya ya 3 sampai 4 bulan bulan mbak. Pendapatan yang diperoleh sekitar 200ribuan tiap panen pisang mbak. Kalau cabai, kami menanam cabai rawit mbak. Pendapatan cabai rawit tiap panen bisa 300ribuan mbak. Soalnya juga lahan yang saya punya sempit jadi saya cuman menanam beberapa pisang dan cabai saja." (H, 41Th)

Berdasarkan beberapa wawancara yang dilakukan peneliti dapat disimpulkan bahwa petani kopi yang memiliki lahan sempit hanya menanam beberapa tanaman lahan tumpang sari saja, contohnya pisang dan cabai yang hanya ditanam beberapa saja. Pisang tersebut nantinya akan dijual disalah satu seseorang yang ada di Desa Harjomulyo yang biasa memborong hasil dari panen pisang dan juga cabai, yang kemudian akan dijual di kota dan juga Pasar. Sehingga petani kopi di Desa Harjomulyo sebagai tangan pertama dan hanya mendapatkan keuntungan yang sedikit. Pendapatan petani kopi setiap panen tanaman lahan tumpang sari sekitar Rp 200.000 sampai dengan Rp 300.000, dengan waktu 3 sampai 4 bulan.

\section{b) Pembuatan Gerai dari Bambu}

Pembuatan kerajinan gerai dari bambu dilakukan petani kopi untuk menutupi kekurangan pendapatan yang ada. Pekerjaan sampingan ini, dilakukan agar petani kopi tidak hanya bergantung pada pekerjaan utama sebagai petani kopi saja melainkan dapat melakukan kegiatan pekerjaan lain yang bisa menghasilkan pendapatan lebih untuk memenuhi kebutuhan yang pada dasarnya semakin bertambahnya waktu semakin meningkat dan kompleks.

Pembuatan gerai dari bambu ini menjadi salah satu upaya untuk memenuhi kebutuhan hidup petani kopi selain dari pekerjaan utama sebagai petani kopi. rata-rata petani kopi bekerja sampingan membuat kerajinan gerai dari bambu, karena dirasa membuatnya lumayan mudah, bahan bakunya melimpah, dapat dikerjakan dihalaman rumah, dan keuntungannya pun lumayan banyak. Seperti yang diungkapkan oleh salah satu petani kopi:

"Untuk memenuhi kebutuhan sehari-hari, saya dan keluarga saya biasanya membuat gerai dari bambu mbak. Keuntungannya lumayan, dan dapat setiap hari dijual, tergantung dari banyaknya yang kami buat.

Semakin banyak yang dibuat, ya semakin banyak pula pendapatan yang kami peroleh. Gerainya ada yang warna hitam dan hijau mbak terus kami jual ke pengepul" $\left(H, 35^{\text {Th }}\right)$.

Berdasarkan wawancara tersebut membuktikan bahwa petani kopi membuat gerai dari bambu ada 2 macam jenisnya, ada yang berwarna hitam dan ada yang berwarna hijau. Petani kopi yang kami teliti kebanyakan setiap harinya membuat gerai dari bambu yang berwarna hijau, karena bahan bakunya tidak susah diperoleh, cepat, dan harganya lebih murah dibandingkan dengan bahan baku bambu yang berwarna hitam. Namun petani kopi tetap membuat gerai dari bambu yang berwarna hitam jika pengepul memesan kepada petani kopi.

Pengepul yang dimaksud disini adalah, salah satu seseorang yang memborong hasil dari gerai bambu yang sudah dibuat oleh beberapa petani kopi, biasanya dibawa dengan mobil Pick Up untuk dijual kembali kepada orang-orang yang menjadi penglah gerai dari bambu. Karena petani kopi disini membuat gerai dari bambu masih dalam keadaan biasa yang belum di poles dan di cat atau di plitur. Sehingga keuntungan petani kopi hanya beberapa persen saja, karena petani kopi yang membuat kerajinan gerai dari bambu ini menjadi tangan pertama yang menjualnya kepada pengepul.

\section{c) Bekerja Keluar Kota}

Bekerja keluar kota ini merupakan salah satu pekerjaan sampingan yang dipilih beberapa petani kopi untuk menambah pendapatan utama untuk memenuhi kebutuhan sehari-hari. Karena pendapatan utama diperoleh 1 tahun sekali, maka keluarga petani kopi tidak bisa memenuhi kebutuhan hidupnya dalam sehari-hari, padahal semakin bertambahnya waktu, kebutuhan hidup dalam sehari-hari semakin bertambah. Pekerjaan ini ada beberapa macam dari penyataan yang telah diungkapkan oleh beberapa petani kopi, ada yang bekerja di Bali sebagai Kuli Bangunan dan ada yang bekerja di Banyuwangi menjaga Toko Gerai yang sudah dikemas dengan warna yang menarik. 
Pendapatan utama yang diterima oleh setiap petani kopi ini berbeda-beda, hal ini disebabkan sesuai dengan luas lahan yang dimilikinya. Sama halnya dengan pendapatan sampingan yang dikerjakan oleh petani kopi, walaupun sama-sama memiliki pekerjaan sampingan namun pendapatannya tetap berbeda. Pendapatan sampingan yang dilakukan oleh beberapa petani kopi yaitu dengan membuat gerai dari bambu, menanam tanaman lahan tumpang sari, dan bekerja keluar kota. Berbagai macam pekerjaan sampingan dilakukan petani kopi untuk memenuhi kebutuhan hidupnya dan kebutuhan hidup keluarga petani kopi. Rata-rata pendapatan sampingan perbulannya mencapai Rp 1.400 .000 sampai Rp 3.500.000, kemudian jika di total pertahun kira-kira mencapai Rp 30.000.000 sampa Rp 36.000.000 per tahun. Sehingga pendapatan sampingan tersebut menjadi upaya petani kopi untuk memenuhi kebutuhan hidup petani kopi dan kebutuhan hidup keluarga petani kopi.

Adapun pendapatan sampingan yang diterima oleh petani kopi di Desa Harjomulyo Kecamatan Silo Kabupaten Jember adalah:

Tabel 2. Pendapatan Sampingan Petani Kopi

\begin{tabular}{|c|c|c|c|}
\hline No. & Nama & Pekerjaan Sampingan & Pendapatan Per Bulan \\
\hline 1 & Bapak Hengki & $\begin{array}{l}\text { a. Tumpang Sari (Pisang, cabai) } \\
\text { b. Membuat Gerai dari Bambu } \\
\text { c. Bekerja keluar kota (Bali) }\end{array}$ & $<\operatorname{Rp} 3.500 .000$ \\
\hline 2 & Bapak Syamsul & $\begin{array}{l}\text { a. Tumpang Sari (Pisang dan cabai) } \\
\text { b. Membuat Gerai dari Bambu }\end{array}$ & $<\operatorname{Rp} 2.000 .000$ \\
\hline 3 & Bapak Warsis & $\begin{array}{l}\text { a. Tumpang Sari (Pisang) } \\
\text { b. Membuat Gerai dari Bambu }\end{array}$ & $<\operatorname{Rp} 1.500 .000$ \\
\hline 4 & Bapak Khalik & $\begin{array}{l}\text { a. Tumpang Sari (Pisang, cabai) } \\
\text { b. Membuat Gerai dari Bambu } \\
\text { c. Bekerja keluar kota (Banyuwangi) }\end{array}$ & $<\operatorname{Rp} 3.200 .000$ \\
\hline 5 & Bapak Junaidi & $\begin{array}{l}\text { a. Tumpang Sari (Pisang) } \\
\text { b. membuat Gerai dari Bambu }\end{array}$ & $<$ Rp 1.400 .000 \\
\hline
\end{tabular}
Jember: data diolah (2017)

Berdasarkan tabel di atas dapat dijelaskan bahwa petani kopi di Desa Hajomulyo Kecamatan Silo Kabupaten Jember memiliki pendapatan sampingan yang tidak sama, karena tergantung dari sedikit banyaknya pekerjaan sampingan yang dilakukan oleh petani kopi. Berbagai macam upaya yang dilakukan petani kopi bertujuan untuk memenuhi kebutuhan pokok keluarganya. Pemenuhan kebutuhan keluarga merupakan kegiatan dimana petani kopi memenuhi kebutuhan seluruh anggota keluarganya.

\section{Pemenuhan Kebutuhan Petani Kopi}

Setiap manusia memiliki kebutuhan yang berbeda, kebutuhan manusia saat ini yang harus terpenuhi terdiri dari kebutuhan pangan, sandang/pakaian, papan/rumah, Pendidikan anak, serta kesehatan. Kelima jenis kebutuhan tersebut harus dipenuhi agar kelangsungan hidupnya berjalan dengan baik. Begitu juga dengan petani kopi di Desa Harjomulyo, pemenuhan kebutuhan hidup setiap petani kopi memiliki cara yang berbeda-beda. Berikut ini akan diuraikan pola pemenuhan kebutuhan hidup petani kopi:

\section{a) Pemenuhan Kebutuhan Pangan}

Kebutuhan pangan merupakan kebutuhan yang sangat penting untuk dipenuhi setiap hari bagi setiap keluarga petani kopi, karena pangan mempunyai peran penting untuk kondisi tubuh manusia. Pemenuhan kebutuhan pangan juga sangat bergantung dari jumlah anggota keluarga yang tinggal pada satu rumah, apabila jumlah anggota keluarga banyak maka pemenuhan kebutuhan makanan juga akan meningkat dan akan meningkatkan jumlah tanggungan petani kopi untuk pengeluaran uang belanja setiap harinya. Petani kopi dapat memenuhi kebutuhan hidupnya dan kebutuhan hidup keluarganya melalui pekerjaan sampingan yang mereka lakukan. Karena salah satu pekerjaan sampingan yang petani kopi lakukan, hasilnya dapat setiap hari di terima.

\section{b) Pemenuhan Kebutuhan Sandang}

Kebutuhan sandang sangat penting untuk dipenuhi oleh setiap manusia tak terkecuali oleh petani kopi dan keluarganya, pendapatan yang rendah membuat petani kopi tidak setiap bulan membeli pakaian, melainkan hanya setiap satu tahun sekali. Berdasarkan hasil wawancara yang dilakukan kepada beberapa informan, informan menyatakan bahwa untuk pemenuhan kebutuhan sandang yang sering dilakukan hanya pada saat hari raya Idhul Fitri sedangkan untuk kesehariaannya hanya memakai pakaian yang sudah ada saja. Tidak jarang dari petani kopi membeli pakaian bekas yang masih layak pakai di pasar yang harganya relatif lebih murah.

\section{c) Pemenuhan Kebutuhan Papan}

Kebutuhan papan atau rumah merupakan kebutuhan pokok lainnya yang sangat penting dan menjadi tempat tinggal keluarga. Kebutuhan tersebut harus dipenuhi untuk jangka waktu yang lama. Selain sebagai tempat tinggal, rumah juga sebagai tempat industri atau pembuatan kerajinan (home industry). Petani kopi di Desa Harjomulyo ini sudah memenuhi kebutuhan papannya, karena tempat untuk bersinggah dan istirahat 
adalah milik pribadi, bukan dari kontrakan atau kos-kosan.

\section{d) Pemenuhan Kebutuhan Pendidikan Anak}

Kebutuhan pendidikan pada jaman sekarang merupakan kebutuhan yang sangat penting untuk dipenuhi oleh keluarga. Kebutuhan pendidikan harus dipenuhi oleh setiap informan penelitian yang memiliki anak. Pendidikan yang ditempuh oleh setiap anak petani kopi akan sangat mempengaruhi masa depan anak petani kopi pada saat akan memasuki dunia kerja. Pemilihan kualitas pendidikan tentu sesuai dengan pendapatan seseorang itu sendiri. Semakin besar pendapatan seseorang, maka semakin besar keinginan seseorang dalam memilih pendidikan yang berkualitas. Begitu halnya dengan petani kopi di Desa harjomulyo Kecamatan Silo Kabupaten Jember, kebutuhan pendidikan yang harus dipenuhi oleh meliputi kebutuhan akan uang saku sekolah, seragam sekolah, buku tulis, buku paket, alat tulis, spp, dan lain sebagainya.

\section{e) Pemenuhan Kebutuhan Kesehatan}

Kebutuhan kesehatan keluarga petani kopi mayoritas berpendapatan menengah kebawah. Sehingga pola yang dilakukan petani kopidalam menjaga kesehatannya adalah memilih membeli obat tanpa resep dokter yang dijual bebas dipasaran. Misalnya saat mengeluh sakit kepala atau batuk, mereka memberli obat atau jamu di warung terdekat tanpa harus pergi ke dokter jika dirasakan sakitnya tidak terlalu parah. Namun jika rasa sakitnya dirasa terlalu parah, petani kopi ke dokter atau puskesmas dengan membawa surat miskin yang digunakan untuk kesehatan.

\section{PENUTUP}

\section{Kesimpulan}

Berdasarkan hasil dari penelitian yang dilakukan, peneliti menyimpulkan bahwa petani kopi di Desa Harjomulyo ini tidak bisa memenuhi kebutuhan hidupnya dan kebutuhan hidup keluarganya jika hanya mengandalkan dari pendapatan utama yaitu sebagai petani kopi. Berbagai upaya yang dilakukan dalam pemenuhan kebutuhan hidup petani kopi adalah dengan mencari pekerjaan sampingan. Pekerjaan sampingan yang dikerjakan oleh petani kopi antara lain dengan menanam lahan tumpang sari, membuat gerai dari bambu dan bekerja keluar kota. Upaya tersebut membantu pemenuhan kebutuhan hidup petani kopi melalui mendapatkan pendapatan lain selain dari pendapatan utama.

\section{Saran}

Berdasarkan beberapa hasil yang telah ditemukan pada penelitian ini, kami menyarankan khusunya bagi petani kopi sebaiknya harus lebih berinovasi untuk mengembangkan pertanian kopi kemudian memperluas jaringan dari usaha bambu dan khususnya sisa dari bambu. Sehingga kebutuhan hidup dari para petani kopi lebih mudah terpenuhi.

\section{DAFTAR PUSTAKA}

Anton, D. 2009. Solusi Keberagaman Pangan. Jakarta : Grasindo

Arikunto, S. 2006. Prosedur Penelitian Suatu Pendekatan Praktik. Jakarta : Rineka Cipta

Aziz, M. 2005. Perkembangan Mode dan Pakaian. Yogyakarta : YKIS.

Budiraharjo, E. 2004. Perumahan dan Pemukiman di Indonesia. Bandung : Penerbit Alumni

Bungin, B. 2005. Analisis Data Penelitian Kualitatif, Jakarta : PT Raja Grafindo Persada

Gilarso, T. 2002. Pengantar Ilmu Ekonomi Bagian Mikro. Yogyakarta : Kanisius

Hanafie, R. 2010. Pengantar Ekonomi Pertanian. Yogyakarta : Andi Offset

Mangkunegara, A.P. 2002. Perilaku Konsumen. Bandung : PT. Rafika Aditama

Maryati, S. 2000. Tata Laksana Makanan. Jakarta : PT. Rineka Cipta

Moleong, L. 2011. Metodologi Penelitian Kualitatif. Bandung: PT. Remaja Rosdakarya.

Mubarok, J. 2012. Kamus Istilah Ekonomi. Bandung : CV. Yrama Widya

Rahardjo, P. 2012. Panduan Budidaya dan Pengolahan Kopi Arabika dan Robusta. Penebar Swadaya. Jakarta

Sumardi, M. 2002. Sumber Pendapatan Kebutuhan Pokok dan Perilaku Menyimpang. Jakarta : CV. Rajawali

Todaro, M.P. 2004. Pembangunan Ekonomi di Dunia Jilid I Edisi kedelapan. Jakarta : Erlangga 